\title{
Puzzle Game With a Combination of Forward Chaining and Backward Chaining Methods
}

\author{
Jonson Manurung \\ Rekayasa Perangkat Lunak, STMIK Pelita Nusantara, Indonesia \\ Email: jonsonmanurung27@gmail.com
}

\begin{tabular}{ll}
\hline Keywords & $\begin{array}{l}\text { Abstract. This research discusses how to find a solution in the secret code puzzle game. } \\
\text { Because the author sees a fairly difficult solution in the game, a solution is needed to get } \\
\text { the answer. In this secret code puzzle game, the writer uses four methods to find a } \\
\text { solution, namely: Forward Chaining and Backward Chaining. The purpose of this final } \\
\text { project is to create software to find a secret code puzzle game solution that we usually } \\
\text { play in IQ test games. Explain how the four methods used by the author to find a solution } \\
\text { werch for solutions } \\
\text { werk and also compare the speed of the four methods used to find out which method is } \\
\text { the fastest. The results achieved are the authors make software in order to determine } \\
\text { which method is the fastest and which method is late in solving the questions provided so } \\
\text { that the author can find out which method is suitable for finding solutions in the secret } \\
\text { code puzzle game and also the author succeeded in making the game. The secret code } \\
\text { puzzle becomes a computer game }\end{array}$ \\
\end{tabular}

\section{INTRODUCTION}

Puzzle games are a form of the game that requires logic sharpening and sometimes using certain tricks to solve them. These games can use methods in Artificial Intelligence (AI) to find solutions. In literature, you can find various types of puzzle games. One type of puzzle that is quite interesting is the secret code puzzle game [1].

The working procedure of this puzzle game can be described as follows, provided an SBox table with size men,where $m$ is the number of table rows representing the letters that will be represented by the numbers concerned and $\mathrm{n}$ is the number of table columns represents the number of numbers used in the game. After that, you will be given a series of numbers that represent a certain word. The goal of this puzzle game is to guess the word that is represented. This puzzle game will be difficult to solve manually if one number can represent several letters on the S-Box and also if the word to be guessed is long [2].

In addition, the word you are going to guess can also have many possibilities, which makes the game even more interesting and challenging. The process of finding a solution to this puzzle game can use forward and backward chaining methods. The compound inference that connects a problem with a solution is called a "chain". The chain that is passed from the problem to the solution is called the "forward chain", which is reasoning from facts to conclusions based on these facts. The chain that is passed from hypothesis to problem is called the "backward chain", which is the achievement of goals through sub-objectives [2].

\section{METHOD}

\subsection{Automatic Reasoning and Proof of Theorem}

The interesting side of proving automatic theorems lies in the rigidity and generality of logic. Since it is a formal system, logic borrows logic itself for automation. Various problems, in general, can be described by representing problem descriptions and information about the relevant causes of problems as logical axioms and treating the problem as a theorem to be proven [3], [4]. 
Unfortunately, early attempts to write proof theorems failed to be used to develop a system that could consistently solve complex problems. This is due to the ability of each logic system with complex reasoning to give rise to an infinite number of theorems that can be proven without a powerful technique (heuristic search method) to guide the search.

\subsection{Circumstance Space Problems and Basic Search Techniques}

Search or tracking is a technique for solving AI problems. The success of a system is determined in part by its success in search and matching. The basic search technique provides a key to many important settlement histories in the AI field. There are several applications that use this search technique, namely [5]:

- Game boards and puzzles (tic-tac-toe, chess)

- Scheduling and routing problems (traveling salesman problem)

- Parsing language and its interpretation (search for structure and meaning)

- Programming logic (finding facts and their implications)

- Computer vision and pattern recognition

- A rule-based expert system

The search concept for a solution in state space is the center of AI which makes AI superior in the field of computer science compared to others, and the principle of AI's contribution to science from this search is a heuristic knowledge-based concept for limitation. and directing the search. Basically, there are two search and tracking techniques: blind search and heuristic search [1].

\subsection{Forward Chaining and Backward Chaining}

The compound inference that connects a problem with a solution is called a "chain". The chain that is passed from problem to solution is called the "forward chain" (reasoning from facts to conclusions based on these facts). The chain that is traversed from hypothesis to problem is called the "backward chain" (achieving goals through sub-objectives). Example: Suppose it has the rule of mode ponen [6][7]:

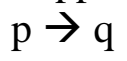

This rule can be used in the causal chain of forwarding inference which draws the conclusion that Bona is an animal if it is known that Bona is an elephant [8], [9].



Figure 1. Example of Rule Illustrations 


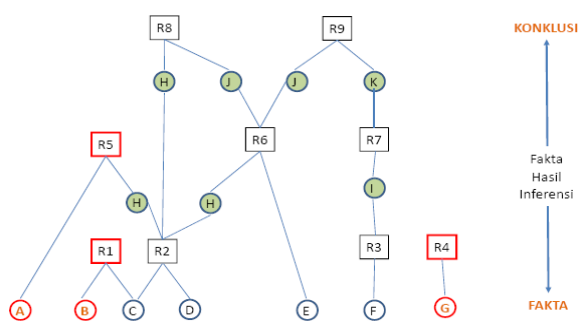

Figure 2. Forward Chaining Illustration [10]

Example:
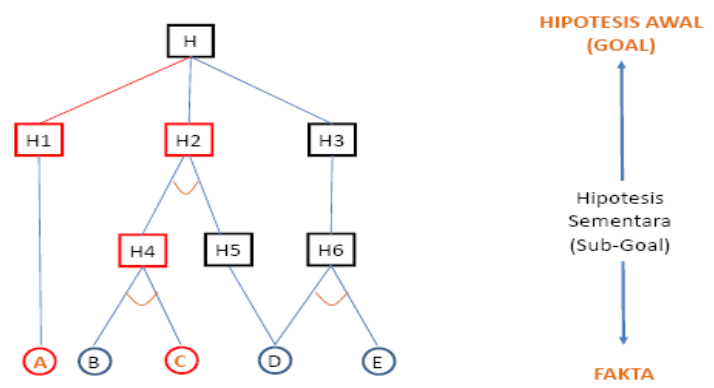

Figure 3 . Backward Chaining Illustration [9]

Rule $1 \quad:$ Y \& D $\rightarrow \mathrm{Z}$

Rule $2 \quad: X \& B \& E \rightarrow Y$

Rule $3 \quad: A \rightarrow X$

Rule $4 \quad: \mathrm{C} \rightarrow \mathrm{L}$

Rule $5 \quad: \mathrm{L} \& \mathrm{M} \rightarrow \mathrm{N}$

\section{a. Secret Code Puzzle Game}

The working procedure of this puzzle game can be described as follows, provided an SBox Table with the size of men, where $m$ is the number of Table rows representing the letters that will be represented by the numbers concerned and $n$ is the number of Table columns represents the number of numbers used in the game. After that, you will be given a series of numbers that represent a certain word. The goal of this puzzle game is to guess the word that is represented. For example, suppose the following S-Box is used:

\begin{tabular}{|c|c|c|c|}
\hline 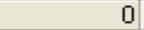 & 1 & 2 & ב \\
\hline$a$ & $b$ & c & d \\
\hline e & f & $\mathrm{g}$ & $\mathrm{h}$ \\
\hline i & i & k & I \\
\hline $\mathrm{m}$ & $\mathrm{n}$ & 0 & $P$ \\
\hline$q$ & I & $s$ & t \\
\hline u & $\mathrm{v}$ & $w$ & $x$ \\
\hline$y$ & $z$ & & \\
\hline
\end{tabular}

For example, given the input code $=1012$, the solution search process is as follows:

Jurnal Info Sains : Informatikan dan Sains is licensed under a Creative Commons Attribution-Non Commercial 4.0 International License (CC BY-NC 4.0) 


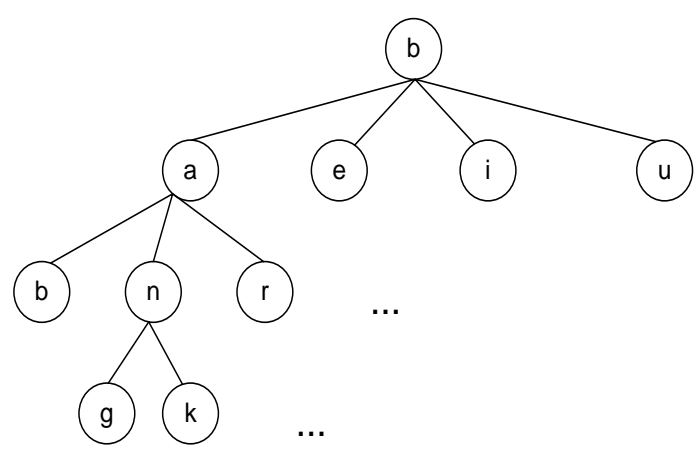

Figure 4. Forward Chaining Tracking Tree:

The tracing tree Figure above is the tracing tree Figure of the example problem above. The search process will start from the letter ' $b$ ' because the first digit of the input code is number 1. After that, the process will continue to the next number, which is the number 0 . Because in Indonesian, the next letter that follows the letter ' $b$ ' cannot be a letter ' $m$ ', ' $q$ ' and ' $y$ ' (because there are no words that start with 'bm', 'bq' and 'by' in Indonesian), the possible letters are letters' a ',' e ',' i 'and' u '. And so on, until a possible solution is obtained.

\section{RESULTS AND DISCUSSION}

\subsection{Object Identification}

The Secret Code Puzzle game is a type of puzzle game to guess the actual word that represents a given series of numbers, where each number can represent several letters and will be formulated using the S-Box. The less number of columns in the S-Box, which means that each number represents more letters, will make this puzzle game even more difficult to solve. Also, if the number line given is getting longer, the manual solving process of this puzzle game will take a lot of time and effort. Also, until now, this Secret Code Puzzle puzzle game is still not available to play on a computer. This is the basis for consideration in making this Secret Code Puzzle game completion software.

\subsection{Define Structure}

In this study, a tree structure was used as an aid in estimating the possible conditions in solving the Secret Code Puzzle game. To better understand the complete process of the Secret Code Puzzle game using the AI search method, a simple example is given below:

Suppose that an S-Box is given:

\begin{tabular}{|l|l|}
\hline & 1 \\
\hline$w$ & $i$ \\
\hline$a$ & $k$ \\
\hline$r$ & $b$ \\
\hline$q$ & $m$ \\
\hline
\end{tabular}

And given a series of numbers $=2211$, then the process of searching for Indonesian words that represent these numbers can be seen in the following details: 


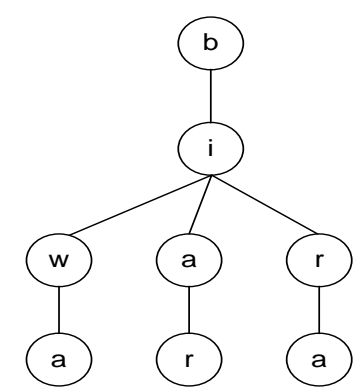

Figure 5 .

Tracking Tree

The functional requirements that must be met by the software are as follows:

1) Algorithms that can be used to search for solutions include Forward Chaining and Backward Chaining algorithms.

2) The letters used include letters $A$ to $Z$ with a special character added -.

3) The maximum number of representative digits inputted is 20 digits.

4) The sequence of numbers to be searched can be typed on the keyboard.

5) The words that the search process will do are input manually and can be stored so that they can be reopened if needed.

6) Table S-Box is also input manually.

7) The software is not case sensitive.

8) The software provides facilities to display supporting theories so that the user knows the basic theory associated with the algorithm used.

9) The software will display the work steps of each algorithm.

10) The software provides the facility to add a word dictionary list.

11) The software will compare the execution time of each algorithm used.

12) The software will display all possible solutions.

13) The software also provides an interface for completing the game manually.

14) If there is no solution, the software will display an error message.

15) The results of the calculation process from the software can be saved into a text file with the extension *.txt.

To formulate the non-functional requirements of the system, an analysis of performance, information, economy, application security, efficiency, and customer service must be carried out. This guide is known as PIECES analysis (performance, information, economic, control, efficiency, and services).

1) Performance

The software uses a screen resolution of 1024 x 768 .

2) Information

The software displays information about the calculation results of each algorithm.

3) Economics

a. The software can be run on the operating system Windows 2000 / Me / XP and above.

$\mathrm{b}$. The software does not require additional support devices in the execution process. The only software required is Microsoft Visual Basic 2008.

4) Control

The software will display an error message when there is an error or system failure.

5) Efficiency

Jurnal Info Sains : Informatikan dan Sains is licensed under a Creative Commons Attribution-Non Commercial 4.0 International License (CC BY-NC 4.0) 
The calculation results of each algorithm can be saved into a text file with the extension *.txt.

6) Service

The software provides the facility to display the previous step or the next step so that the user can make transition arrangements between steps.

\section{CONCLUSION}

This software can be used to solve the Secret Code Puzzle game using the Forward Chaining and Backward Chaining algorithms. From the test results, it is concluded that the search process using the Forward Chaining algorithm has the best execution time among the algorithms used. Meanwhile, the search process using the Backward Chaining algorithm has the worst execution time among the algorithms used. The software can randomize questions in the game section using the help of a word database.

\section{REFERENCE}

[1] M. Y. Fachroni, H. Wibowo, and S. Syaifuddin, "Perancangan Game Physical Puzzle Rolling Kingdom," J. Animat. Games Stud., vol. 4, no. 1, 2018, doi: 10.24821/jags.v4i1.1873.

[2] I. Kurniawan, "Pengaruh Terapi Bermain Game (Puzzle) terhadap Tingkat Nyeri Usia Pra Sekolah Pasca Tindakan Operasi Tutup Stoma Hari Ketiga di Ruang Anak Lantai Dasar RSUP dr. Kariadi Kota Semarang," Karya Tulis Ilm., 2018.

[3] C. K. Edwards, R. K. Landa, S. E. Frampton, and M. A. Shillingsburg, "Increasing Functional Leisure Engagement for Children With Autism Using Backward Chaining," Behav. Modif., vol. 42, no. 1, 2018, doi: 10.1177/0145445517699929.

[4] R. Oktapiani, "Penerapan Metode Forward Chaining Pada Sistem Pakar Kerusakan Komputer," IJCIT (Indonesian J. Comput. Inf. Technol., vol. 02, no. 02, 2017.

[5] R. A. Krisdiawan, "Implementasi Model Pengembangan Sistem Gdlc Dan Algoritma Linear Congruential Generator Pada Game Puzzle," Nuansa Inform., vol. 12, no. 2, 2018.

[6] K. Muludi, R. Suharjo, A. Syarif, and F. Ramadhani, "Implementation of forward chaining and certainty factor method on android-based expert system of tomato diseases identification," Int. J. Adv. Comput. Sci. Appl., vol. 9, no. 9, 2018, doi: 10.14569/ijacsa.2018.090957.

[7] B. Herawan Hayadi, A. Bastian, K. Rukun, N. Jalinus, Y. Lizar, and A. Guci, "Expert system in the application of learning models with Forward Chaining Method," Int. J. Eng. Technol., vol. 7, no. 2.29 Special Issue 29, 2018, doi: 10.14419/ijet.v7i2.29.14269.

[8] E. H. Wijaya and N. Hidayat, "Diagnosis Penyakit Cabai dengan Menggunakan Metode Forward Chaining - Dempster-Shafer," J. Pengemb. Teknol. Inf. Dan Ilmu Komput., vol. 2, no. 12, 2018.

[9] Y. Darmayunata, "Web-Based Expert System Using Backward Chaining Method," Inf. Technol. Comput. Sci., vol. 1, no. 2, 2018.

[10] M. Fauzi, "Sistem Pakar Mendeteksi Kerusakan Keyboard Menggunakan Metode Forward Chaining," J. Sist. Inf. Kaputama, vol. 2, no. 1, 2018. 